\title{
Vertical structure use by the Stout Iguana (Cyclura pinguis) on Guana Island, BVI
}

Christopher A. Cheek ${ }^{1}$, Shay Hlavaty ${ }^{1}$, Krista Mougey ${ }^{1}$, Rebecca N. Perkins ${ }^{1}$, Mark A. Peyton ${ }^{1}$, Caitlin N. Ryan ${ }^{2}$, Jennifer C. Zavaleta ${ }^{1}$, Clint W. Boal ${ }^{3}$, and Gad Perry ${ }^{1}$

${ }^{1}$ Department of Natural Resources Management, Box 42125, Texas Tech University, Lubbock, Texas 79409

${ }^{2}$ The Institute of Environmental and Human Health, Department of Environmental Toxicology, Box 41163, Texas Tech University, Lubbock, Texas 79409 ${ }^{3}$ U.S. Geological Survey, Texas Cooperative Fish and Wildlife Research Unit, Texas Tech University, Lubbock, Texas 79409

\begin{abstract}
The Stout Iguana (Cyclura pinguis) is a critically endangered species endemic to the Puerto Rico Bank and currently restricted to the British Virgin Islands (BVI). Our study on Guana Island, BVI, focused on vertical structure use. Based on previous incidental observations, we hypothesized that Stout Iguanas use vertical structures and that adults and juveniles use such structures differently. In October 2011, we documented movement and vertical structure use by adult $(n=4)$ and juvenile $(n=11)$ iguanas with tracking bobbins. We recorded structure types used, heights attained on structures, distances between structures, and structure sizes. We found that Stout Iguanas used vertical structure more than previously documented. Trees comprised a significantly greater $(\mathrm{P}<0.001)$ proportion of structures used by juveniles than by adults, whereas rocks comprised the greatest proportion of structures used by adults. In addition to differential structure use, juveniles climbed significantly higher $(2.4$ vs. $0.9 \mathrm{~m}$ on average; $\mathrm{P}<0.001)$ than adults. We found no difference in the diameter or distance between structures used by adults and juveniles. Our results suggest that vertical structure use may be an important habitat element for free-ranging juvenile Stout Iguanas. Habitat management that provides vertical structure may be advantageous for the conservation of this species.
\end{abstract}

$\mathrm{T}$ The Stout Iguana (Cyclura pinguis, Fig. 1) is endemic to the Puerto Rico Bank and has been listed as critically endangered (Mitchell 1996, USFWS 1999). When Stout Iguanas were first described in 1917, the species was restricted to the flat and sandy island of Anegada (British Virgin Islands, BVI; Fig. 2). The common name "Anegada Iguana" is also in frequent use, despite subfossil evidence found in caves and in middens that indicates the species once inhabited much or all of the Puerto Rico Bank (Pregill and Olson 1981, Stephen 2012). The reduced distribution of Stout Iguanas was likely due to the habitat loss caused by rising sea levels and the introduction of non-native herbivores and direct predation by humans (Pregill and Olson 1981, Lazell 2005).

Anegada is flat (highest elevation $<10 \mathrm{~m}$ ), highly sandy, and the eastern two-thirds of the island consist of mostly exposed limestone rubble (D'Arcy 1975). Introduced predators, competition with non-native mammalian herbivores, and habitat loss have all contributed to an extensive decline of the Stout Iguana population on the island (Mitchell 1999, Bradley and Gerber 2005, Perry and Gerber 2011). Mitchell (1999) estimated only 164 individuals persisted into the early 1990s. While a headstarting program continues on Anegada, eight iguanas were introduced to privately owned Guana Island (Fig. 3) in 1984 in an effort to conserve the species (Goodyear and Lazell 1994). Guana Island is dedicated to tourism and has become a de facto nature preserve. Anegada, which is inhabited by about 200 people, has more anthropogenic disturbance than Guana. Guana also differs dramatically from Anegada in its volcanic origins, steep topography (highest elevation $245 \mathrm{~m}$ ), and a more complex vegetative community (Lazell 2005). The difference in geology, soils, and vegetation initially led to concerns that the iguana introduction would fail. However, the introduced population has done extremely well on Guana (Perry and Mitchell 2003, Perry et al. 2007) and has since served as the source for several subsequent introductions to other islands in the BVI (Perry and Gerber 2011).

Guana Island offers a multitude of vertical structures such as trees, vines, and large boulders (Fig. 4) that are mostly absent on Anegada (Fig. 5). Use of habitat elements not currently available on Anegada could partially explain the population decline of Stout Iguanas there and the observed popu- 


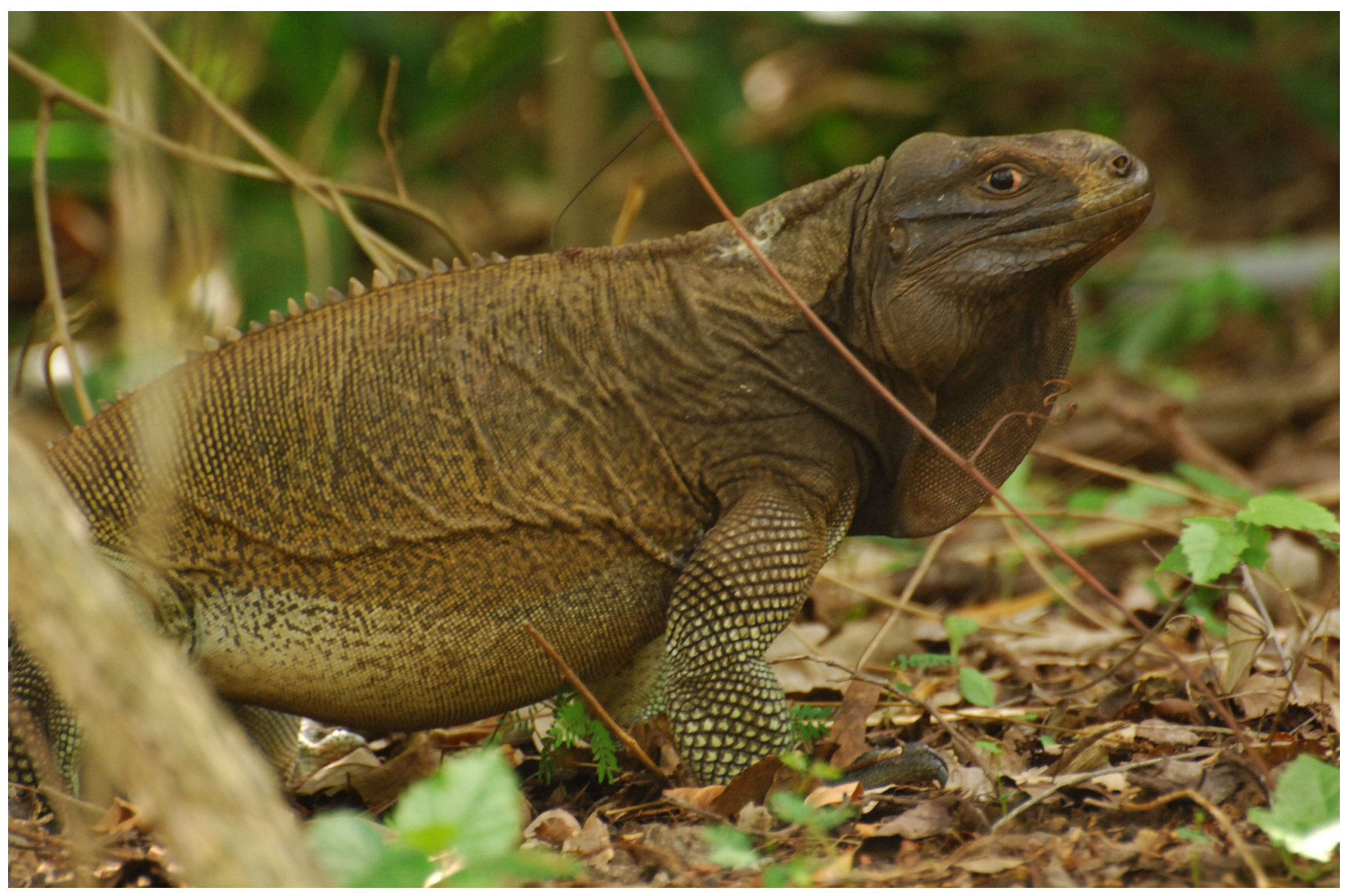

Fig. 1. Adult Stout Iguana (Cyclura pinguis). Photograph by Doug Bell.

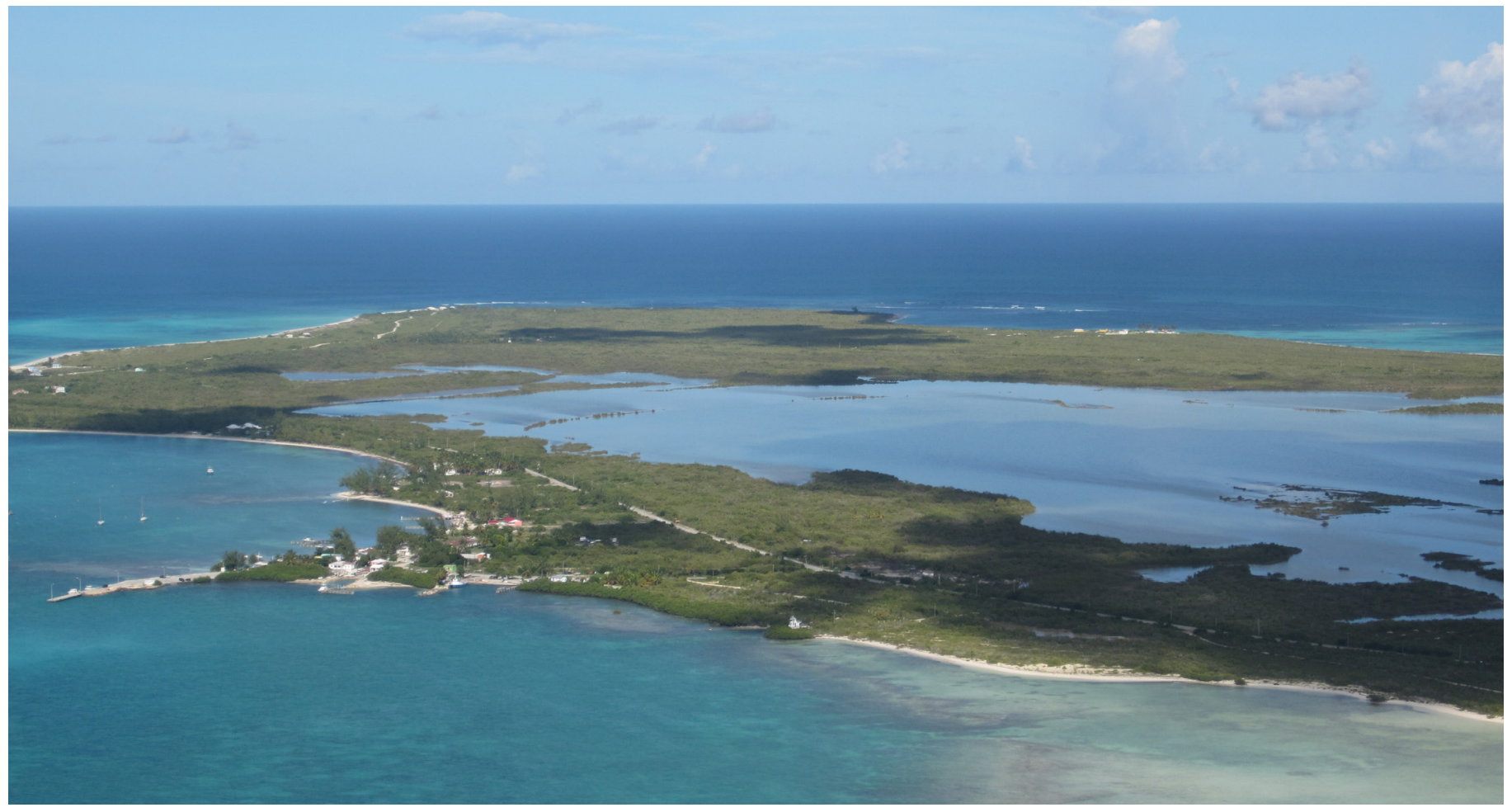

Fig. 2. Aerial photograph of Anegada Island. Photograph by Krista Mougey. 


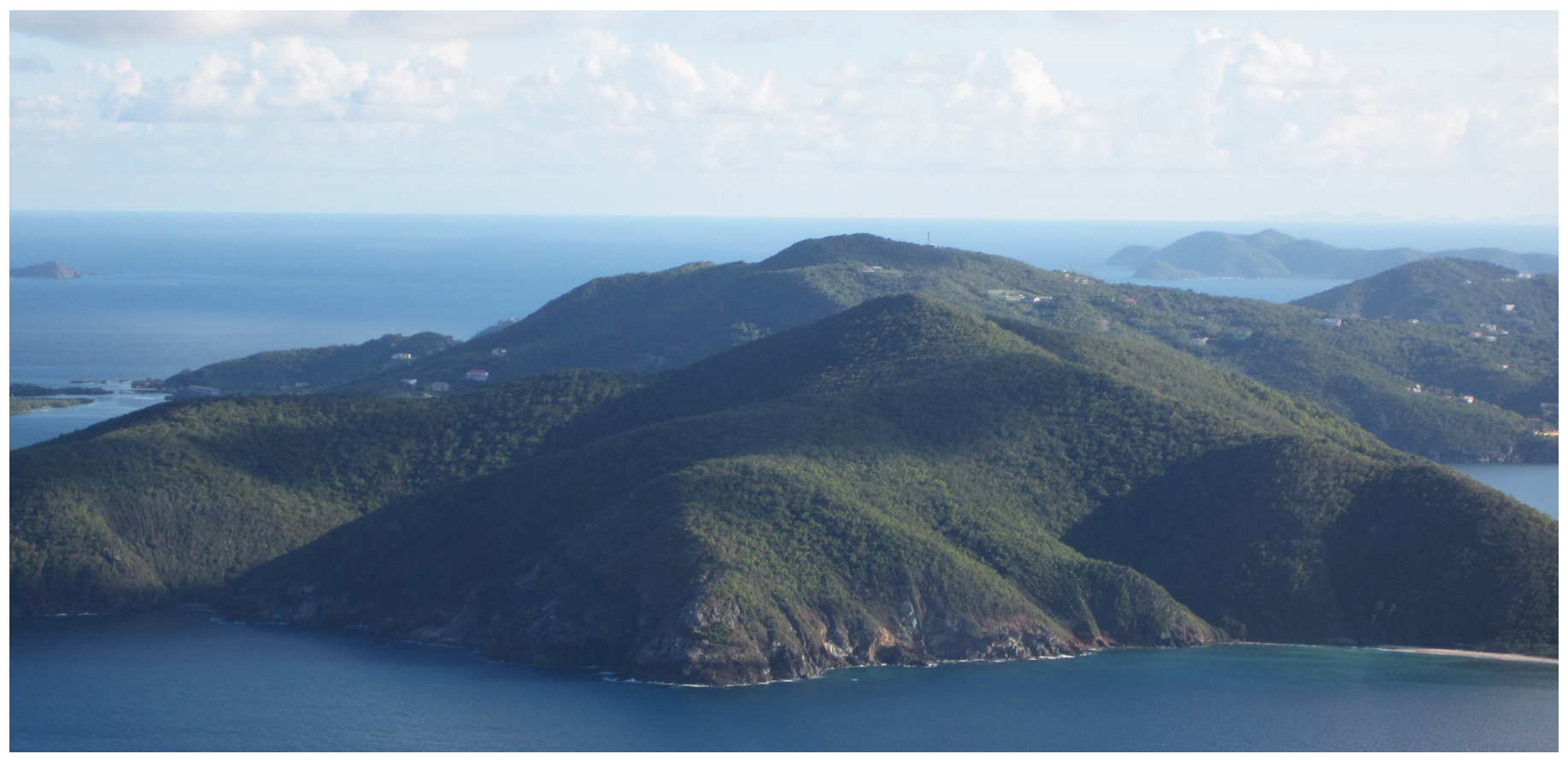

Fig. 3. Aerial photograph of Guana Island. Photograph by Krista Mougey.

lation growth on Guana. We therefore focused our study on two questions: (1) What types of vertical structures do iguanas use on Guana, and (2) how do juveniles and adults use these structures differently?

\section{Materials and Methods}

We tracked adult and juvenile Stout Iguanas that had been captured by hand and fitted with thread bobbins (Wilson 1994) for up to four days. Bobbins (200 m of string) were placed inside a balloon that had been coated with a rubber spray to form a rigid exterior (Performix@ Plasti-Dip). The coated balloons were then glued anterior to the base of the tail on each iguana. The device weighed less than $5 \%$ of animal mass. We released iguanas at capture sites within 24 hours and attached the end of the bobbin string to a fixed object. Upon release, juvenile iguanas usually only ran 1-2 m. Adults tended to flee farther after release and often went straight to a burrow, but were usually active again within a short period. We consequently assumed that iguanas resumed normal behavior shortly after release.

We monitored each string at least once per day and noted the location of the animal if the string was not yet completely dispensed. After the bobbin was completely dispensed or the string was broken, we measured the linear distance traveled by each iguana. We omitted one string that was so fragmented that analysis was meaningless. We recorded the distance between vertical structures (defined as objects on which the iguana climbed more than $15 \mathrm{~cm}$ above the ground), maximum height reached on each structure, type of structure used (trees [live woody vegetation], other vegetation [cacti, vines, logs, stumps, and brush piles], rock [boulders, and rock piles], and cement structures), and the diameter at breast height $(\mathrm{DBH})$ of trees used.

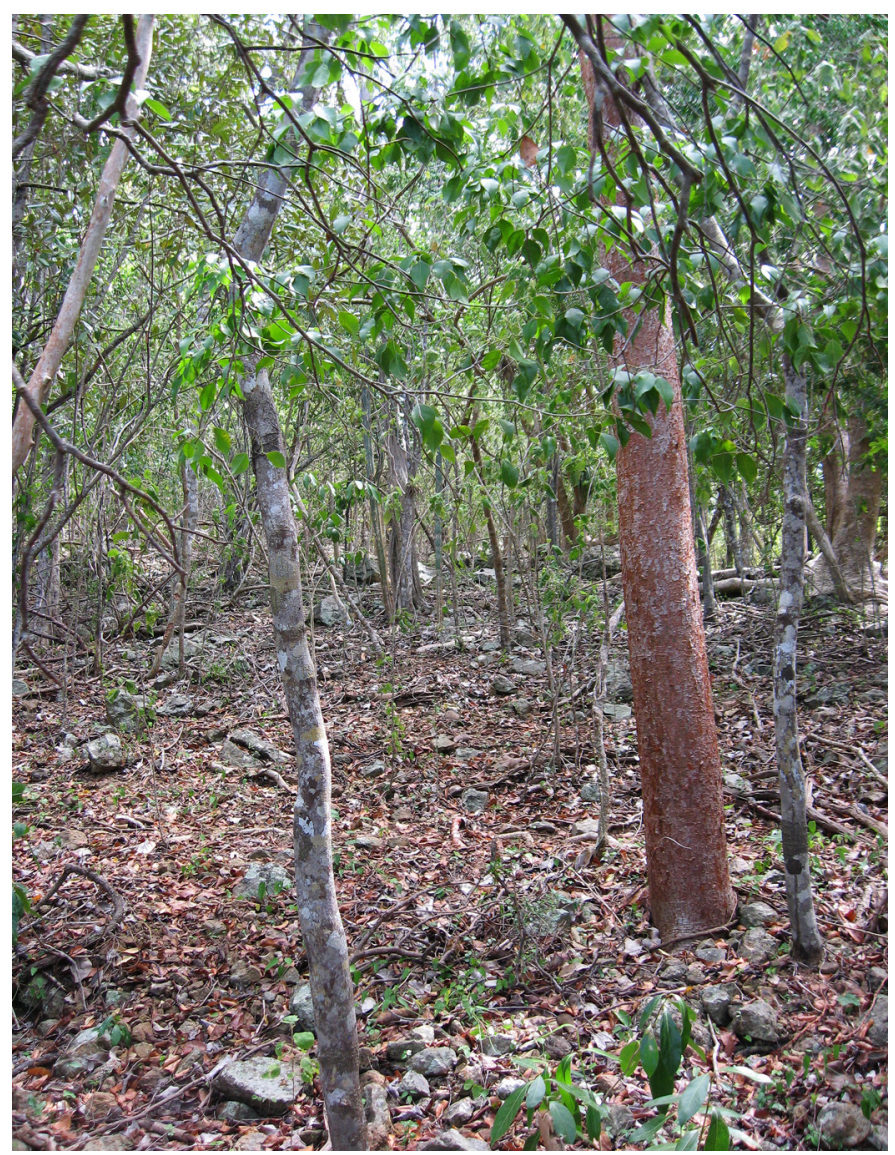

Fig 4. Typical vegetation on Guana Island illustrating the difference in vegetation when compared to Anegada (Fig. 5). Photograph by Krista Mougey. 


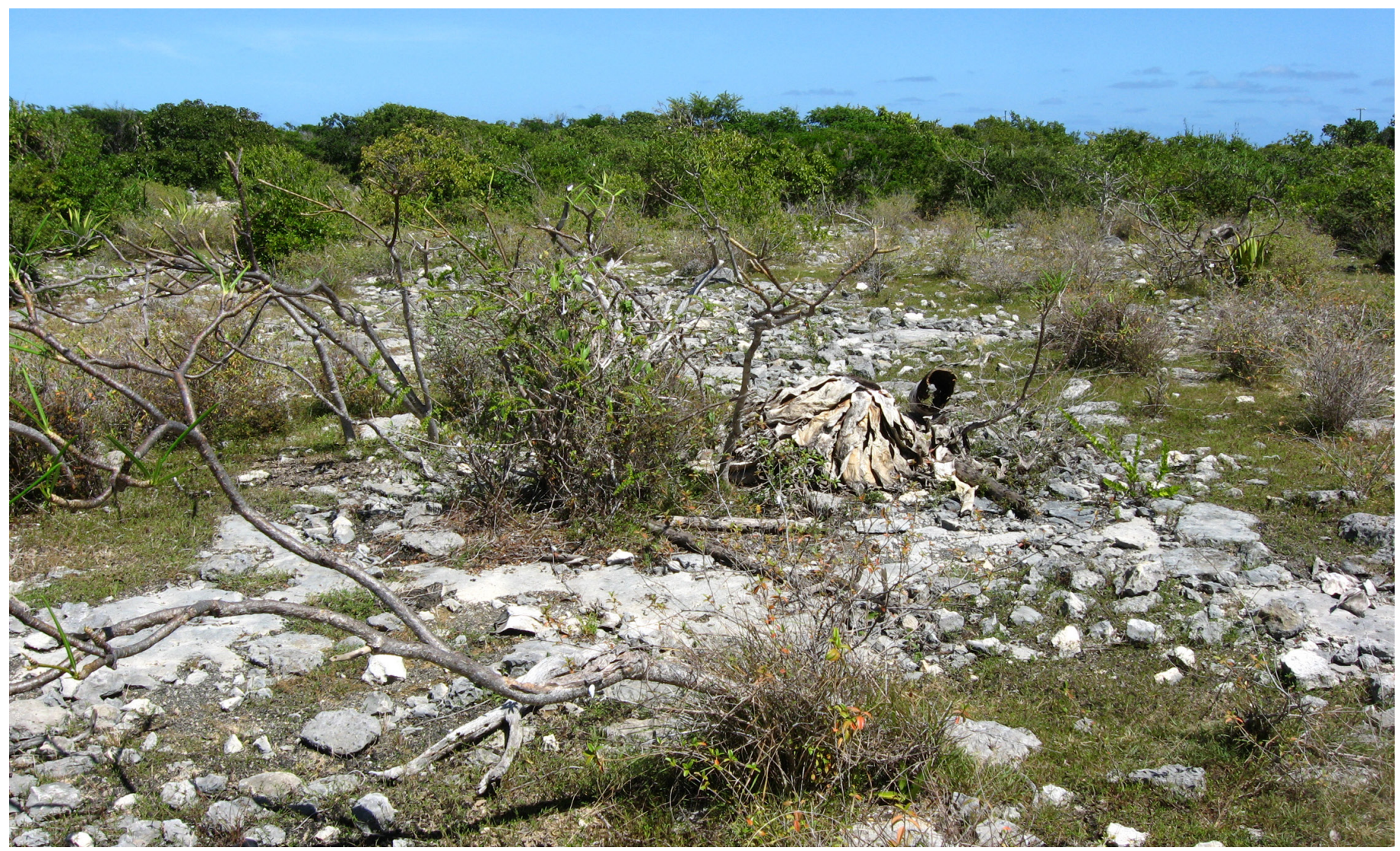

Fig 5. Typical Vegetation on Anegada Island. Photograph by Krista Mougey.

We tested for differences in observed height on vertical structure used between juvenile and adult iguanas with a Wilcoxon rank test and used a two-sided Fisher's exact test to assess differences between adults and juveniles in the types of vertical structure used. Means are given \pm one standard error. Data were analyzed using software $\mathrm{R}$ version 2.15.1 ( $\mathrm{R}$ Development Core Team 2008). All use of live animals was conducted under Texas Tech University Animal Care and Use Protocol 10068-09.

\section{Results and Discussion}

We measured a total distance of $407 \mathrm{~m}$ of string for juveniles $(\mathrm{n}=11)$ and $192 \mathrm{~m}$ for adults $(\mathrm{n}=4)$. Types of structures utilized by adult and juvenile iguanas were significantly different (Fisher's exact test, $\mathrm{P}<0.001$; Fig. 6). Adults mainly used rocks and low vegetation. Conversely, juveniles primarily used trees (Fig. 7) when climbing above ground level and often were observed in trees during inactive periods (900$1500 \mathrm{~h}$ ), as previously suggested by Gebert (2011). The average maximum heights attained by adults $(0.9 \pm 0.2 \mathrm{~m})$ and juveniles $(2.4 \pm 0.2 \mathrm{~m}$ ) also differed significantly ( $\mathrm{W}=327.5$, $\mathrm{df}=53, \mathrm{P}<0.001$; Fig. 8). Juveniles also were observed in the canopy during twilight hours (5 individuals, 12 observations) and presumably passed the inactive nocturnal period in these arboreal locations.
Juvenile and adult iguanas also differed in structure choice during inactive periods. Juveniles spent inactive periods in trees $(\mathrm{n}=5)$, whereas adults tended to use burrows ( $\mathrm{n}$ = 3) near structures such as boulders and brush piles. During our brief study we observed adult bobbin string coming in and out of individual burrows multiple times, indicating repeated use within a single day. We suspect that adults spend the majority of the day in the burrows and leave only a few times to feed, thermoregulate, and conduct social interac-

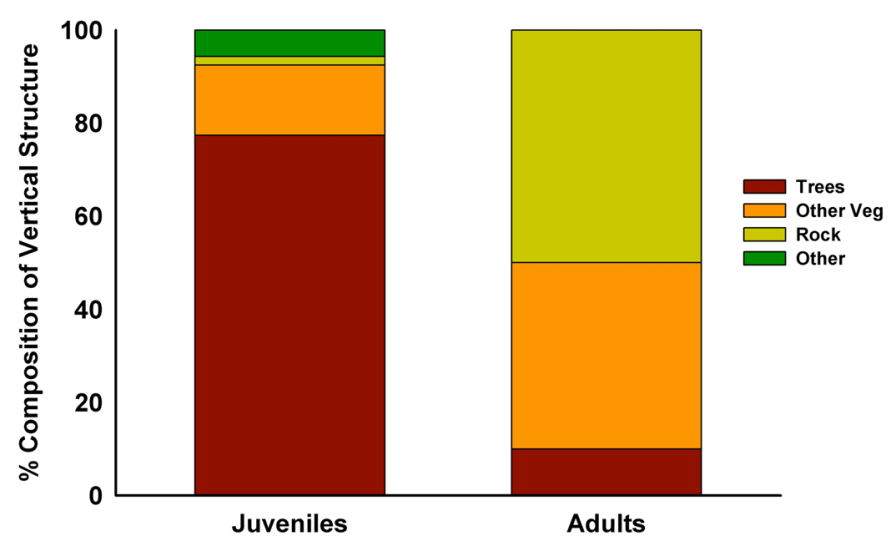

Fig. 6. Percent composition of vertical structure used by adult and juvenile Stout Iguanas. A total of 53 structures were used by juveniles and nine by adults. 


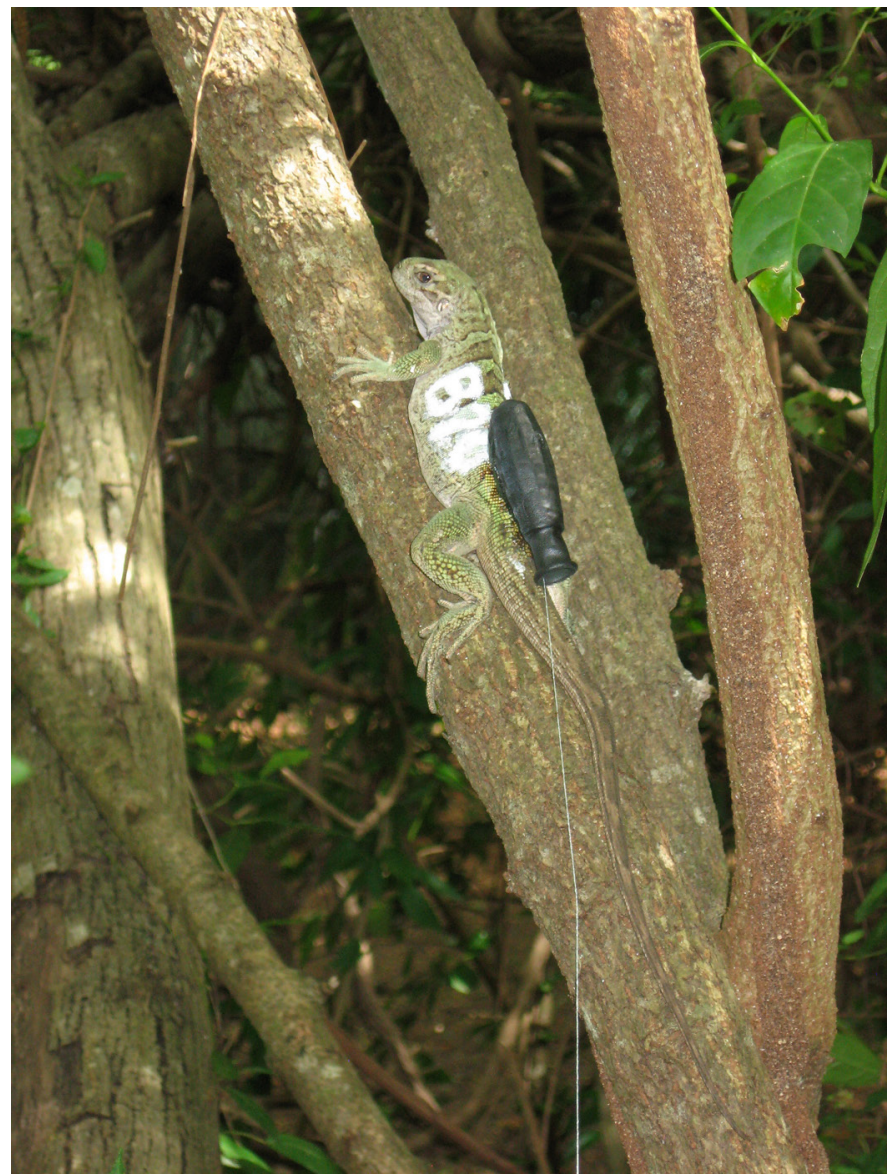

Fig. 7. Juvenile Stout Iguana with tracking bobbin utilizing a tree limb. Photograph by Krista Mougey.

tions. Iguanas also may enter burrows to avoid humans traveling nearby. Additional studies of burrows would be desirable, as the substrate on Guana (volcanic rock) is substantively different from the limestone cavities available on Anegada and throughout much of the range of the genus Cyclura (Bradley and Gerber 2005).

The mean total distance of string measured was $36.6 \pm$ $18.7 \mathrm{~m}$ for juveniles and $47.9 \pm 13.7 \mathrm{~m}$ for adults. The mean distance between vertical structures used was similar for adults $(8.4 \pm 1.7 \mathrm{~m})$ and juveniles $(8.6 \pm 1.4 \mathrm{~m})$, but our observations indicated that the method of movement between structures differed. Adults moved almost exclusively along the ground between structures. In contrast, string from juvenile iguana bobbins was usually observed on vertical structures, indicating movement along vines and shrubs to move between trees. Trees used by adults (DBH $40 \pm 18 \mathrm{~cm}$ ) were larger than those used by juveniles $(11 \pm 3 \mathrm{~cm}$ ), but small samples (only two adults used trees) precluded statistical analysis. However, the difference in body size and mass of juveniles (approximately $60 \mathrm{~g}$ ) and adults (typically 1-6 kg; Perry et al. 2007) could preclude adults from using small trees or traveling in the canopy as juveniles commonly do.

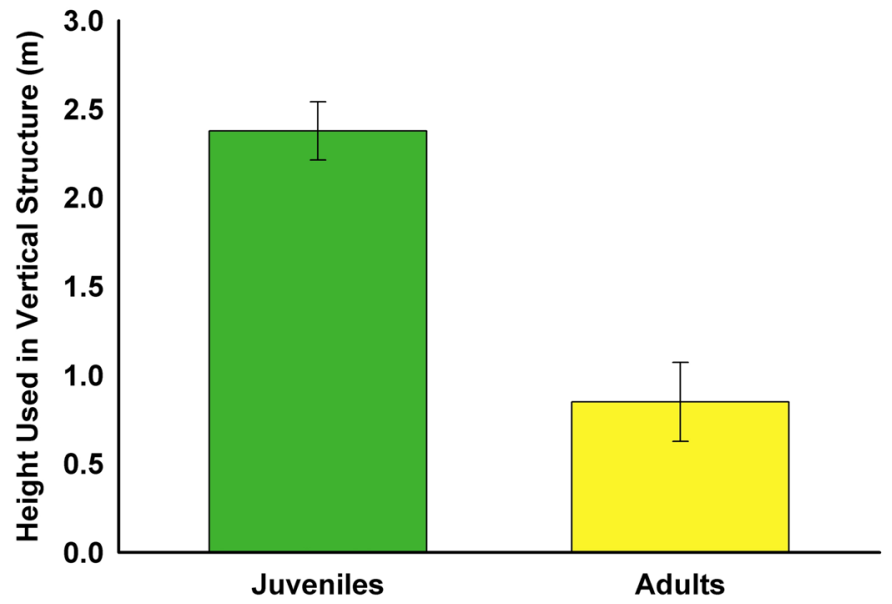

Fig. 8. Mean height used on vertical structures by adult and juvenile Stout Iguanas.

Thermoregulation is an important activity for Stout Iguanas, which maintain a high body temperature during active periods (Lemm and Alberts 2012). The presence of juveniles well above ground during inactive periods may be related to availability of sunlight early and late in the day, when the forest floor is already shaded. Use of vertical structures allows juvenile iguanas to bask later into the evening and earlier in the morning, presumably allowing them to sustain high body temperatures, increasing metabolism, digestion, and growth rates (Troyer 1987). In addition, the use of tree canopies by juveniles during inactive periods could be an evolved behavior for avoiding predators. Vertical structure use is likely advantageous for avoiding native daytime predators such as Puerto Rican Racers (Borikenophis [formerly Alsophis] portoricensis, LeVering and Perry 2003), as well as introduced predators such as feral cats (Bradley and Gerber 2005).

Habitat composition differs greatly between the lowlying, limestone island of Anegada and the much higher volcanic Guana Island. On Anegada, where relatively little vertical structure exists, juveniles mostly use sandy scrub areas that have little tall vegetation (D'Arcy 1975). As Stout Iguanas were only known from Anegada until fairly recently, and as many species in the genus Cyclura typically are found on low-lying limestone islands (Bradley and Gerber 2005), assuming that Anegada provided ideal habitat for iguanas was reasonable. However, our data suggest that this species is well suited, and perhaps even adapted, to the richer vegetation diversity and volcanic geology typical of the rest of the BVI (Fig. 9). Cyclura pinguis is the most basal member of its genus and is not greatly differentiated genetically from a clade including the genera Iguana, Sauromalus, Ctenosaura, Conolophus, and Amblyrhynchus (Malone et al. 2000). These are Central and South American species typically found in relatively dry or edge habitats (Burghardt and Rand 1982), as are many modern Cyclura. Central America, where Iguana 


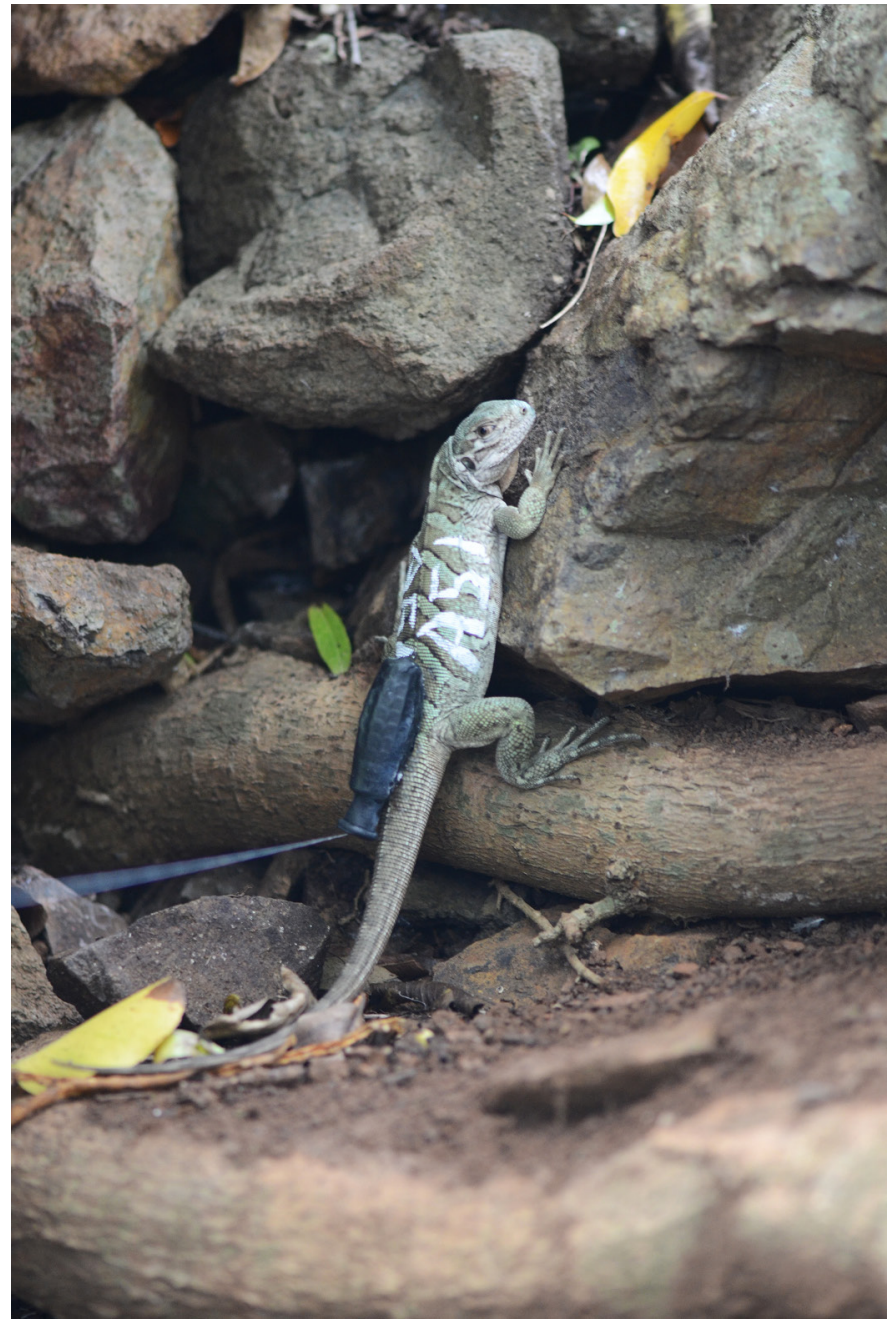

Fig. 9. Juvenile Stout Iguana with bobbin using vertical rock structure. Photograph by Doug Bell.

and Ctenosaura are found, is primarily volcanic (Malzer and Fiebig 2008). This also is the case for the Galapagos Islands, where Conolophus and Amblyrhynchus are found (White et al. 1993). In fact, although many Caribbean islands on which Cyclura are found are overlain with limestone, other Caribbean islands where other iguanas are found are of volcanic origins (Powell et al. 2005). When the ancestors of $C$. pinguis arrived in the Puerto Rico Bank some 33-35 million years ago (Stephen 2012), they therefore would have likely shared the ancestral state of not being limestone specialists. We consequently suggest that Stout Iguanas should perhaps be considered a refugee species (sensu Kerley et al. 2012) on Anegada, already confined to suboptimal habitats when early reports were published. This interpretation also could help explain the success of repatriated populations on Guana and Necker Islands (Perry and Gerber 2011).

Given that published observations from Anegada, starting with the work of Carey (1975) and continuing today (Lemm and Alberts 2012), have almost exclusively been limited to adults, that the importance of vertical structure to the species on that island had not been addressed is not surprising. Protecting and revegetating core iguana areas on Anegada, as called for by previous authors (Perry and Gerber 2011, Mitchell et al. 2011), would likely be highly efficacious for conservation efforts there. Removal of non-native herbivores from Anegada and other islands where they might be affecting iguana habitats and diets is a feasible management option (Island Conservation, 2006), and could be a part of any revegetation plan and is fully compatible with the existing species recovery plan (Burton and Bloxam 2006).

\section{Acknowledgments}

We thank J. Lazell for sharing his insights and the staff of Guana Island for technical assistance. We also thank Katrina Street, Matthew Gifford, and Robert Powell for their assistance in capturing iguanas. The Conservation Agency provided financial support through a grant from the Falconwood Foundation. The use of trade, firm, or product names is for descriptive purposes only and does not imply endorsement by the U.S. Government. This is manuscript T-9-1247 of the College of Agricultural Sciences and Natural Resources, Texas Tech University.

\section{Literature Cited}

Bradley, K.A. and G.P. Gerber. 2005. Conservation of the Anegada Iguana (Cyclura pinguis). Iguana 12:78-85.

Burghardt, G.M. and A.S. Rand. 1982. Introduction, pp. 1-4. In: G.M. Burghardt and A.S. Rand (eds), Iguanas of the World: Their Behavior, Ecology, and Conservation. Noyes Publications, Park Ridge, New Jersey.

Burton, F.J. and Q.M.C. Bloxam (facilitators). 2006. Anegada Iguana, Cyclura pinguis species recovery plan, 2006-2010 (www.iucn-isg.org/wp-content/ uploads/2013/03/Anegada_Iguana_SRP_2006-2010.pdf).

Carey, W.M. 1975. The Rock Iguana, Cyclura pinguis, on Anegada, British Virgin Islands, with notes on Cyclura ricordi and Cyclura cornuta of Hispaniola. Bulletin of the Florida State Museum of Biological Sciences 19:189-233.

D'Arcy, W.G. 1975. Anegada Island: Vegetation and flora. Atoll Research Bulletin (188): $1-40$.

Gebert, K. 2011. What Stout Iguanas (don't) do all day. Reptiles \& Amphibians 18:110-115.

Island Conservation. 2006. Restoration of the Anegada Rock Iguana Populations on Anegada Island, British Virgin Islands. Unpublished report to the Government of the BVI. Road Town.

Lazell, J. 2005. Island: Fact and Theory in Nature. University of California Press, Berkeley, California.

LeVering, K. and G. Perry. 2003. Cyclura pinguis (Stout Iguana, Anegada Rock Iguana). Juvenile predation. Herpetological Review 34:367-368.

Lemm, J.M. and A.C. Alberts (eds.). 2012. Cyclura: Natural History, Husbandry, and Conservation of West Indian Rock Iguanas. Academic Press, San Diego, California.

Malone, C.L., T. Wheeler, J.F. Taylor, and S.K. Davis. 2000. Phylogeography of the Caribbean Rock Iguana (Cyclura): Implications for conservation and insights on the biogeographic history of the West Indies. Molecular Phylogenetics and Evolution 17:269-279.

Malzer, O. and M. Fiebig. 2008. Outline of the geology of the Golfo Dulce region (Costa Rica) and its surroundings in Central America, pp. 23-30. In: A. Weissenhofer, W. Huber, V. Mayer, S. Pamperl, A. Weber, and G. Aubrecht (eds.), Natural and Cultural History of the Golfo Dulce Region, Costa Rica. Stapfia 88, also Kataloge der Oberösterreichischen Landesmuseen N.S. 80. Freistadt, Austria.

Mitchell, N. 1996. Cyclura pinguis. In: IUCN 2013. IUCN Red List of Threatened Species (www.iucnredlist.org). 
Mitchell, N. 1999. Effect of introduced ungulates on density, dietary preferences, home range, and physical condition of the iguana (Cyclura pinguis) on Anegada. Herpetologica 55:7-17.

Mitchell, A.A, J. Lau, L.G. Chemnick, E.A. Thompson, A.C. Alberts, O.A. Ryder, and G.P. Gerber. 2011. Using microsatellite diversity in wild Anegada Iguanas (Cyclura pinguis) to establish relatedness in a captive breeding group of this critically endangered species. Conservation Genetics 12:771-781.

Perry, G. and G.P. Gerber. 2011. Conservation of amphibians and reptiles in the British Virgin Islands: Status and patterns, pp. 105-127. In: A. Hailey, B.S. Wilson, and J.A. Horrocks (eds.), Conservation of Caribbean Island Herpetofaunas. Volume 2: Regional Accounts of the West Indies. Brill, Leiden, The Netherlands.

Perry, G. and N. Mitchell. 2003. Guana and Necker island population assessments 2002. Iguana 10:49.

Perry, G., J. Lazell, K. LeVering, and N. Mitchell. 2007. Body size and timing of reproduction in the highly endangered Stout Iguana, Cyclura pinguis, in the British Virgin Islands. Caribbean Journal of Science 43:155-159.

Powell, R., R.W. Henderson, and J.S. Parmerlee, Jr. 2005. The Reptiles and Amphibians of the Dutch Caribbean: St. Eustatius, Saba, and St. Maarten. St. Eustatius National Parks Foundation, Gallows Bay, St. Eustatius, Netherlands Antilles.
Pregill, G.K. and S.L. Olson. 1981. Zoogeography of West Indian vertebrates in relation to Pleistocene climatic cycles. Annual Review of Ecology and Systematics 12:75-98.

R Development Core Team. 2008. R; A Language and Environment for Statistical Computing. R Foundation for Statistical Computing, Vienna, Austria (www.R-project.org).

Stephen, C.L. 2012. Evolution and biogeography, pp. 3-11. In: J.M. Lemm and A.C. Alberts (eds.), Cyclura: Natural History, Husbandry, and Conservation of West Indian Rock Iguanas. Academic Press, San Diego, California.

Troyer, K. 1987. Small differences in daytime body temperature affect digestion of natural food in an herbivorous lizard (Iguana iguana). Comparative Biochemistry and Physiology. 87A:623-626.

U.S. Fish and Wildlife Service. 1999. Endangered and Threatened Wildlife and Plants 50 CFR 17.12. Division of Endangered Species, U.S. Fish and Wildlife Service, Washington, D.C. (www.fws.gov/endangered/wildlife.html).

White, W.M., A.R. McBirney, and R.A. Duncan. 1993. Petrology and geochemistry of the Galápagos Islands: Portrait of a pathological mantle plume. Journal of Geophysical Research 98:19,533-19,563.

Wilson, D.S. 1994. Tracking small animals with thread bobbins. Herpetological Review 25:13-14. 